\title{
Phytoprotection
}

\section{Evaluation of interactions between Rhynchosporium secalis and Pyrenophora teres on barley}

\author{
A.G. Xue et P.A. Burnett
}

Volume 76, numéro 1, 1995

URI : https://id.erudit.org/iderudit/706079ar

DOI : https://doi.org/10.7202/706079ar

Aller au sommaire du numéro

\section{Éditeur(s)}

Société de protection des plantes du Québec (SPPQ)l

\section{ISSN}

0031-9511 (imprimé)

1710-1603 (numérique)

Découvrir la revue

Citer cet article

Xue, A. \& Burnett, P. (1995). Evaluation of interactions between

Rhynchosporium secalis and Pyrenophora teres on barley. Phytoprotection,

76(1), 1-7. https://doi.org/10.7202/706079ar
Résumé de l'article

Les interactions entre le Rhynchosporiumsecalis et le Pyrenophora teres ont été étudiées sur des plantules d'orge (Hordeum vulgare) cultivées dans une serre et dans des chambres de croissance. À la suite d'inoculations mixtes, les deux agents pathogènes ont colonisé la même feuilles imultanément, mais la surface foliaire portant des symptômes était moindre que celle produite par l'un ou l'autre des deux agents pathogènes utilisés seuls à la même concentration d'inoculum. Sur les plantes inoculées avec les inoculums mixtes, la surface foliaire portant des symptômes induits par le $R$. secalis était grandement inférieure à celle induite par le $P$. teres. La prédominance du $P$. teres sur le $R$. secalis a même été observée quand les inoculations avec le $R$. secalis précédait ou suivait l'inoculation avec le $P$. teres par $24 \mathrm{~h}$. Un antagonisme s'est produit quand les concentrations d'inoculum étaient de 103-104 spores $\mathrm{mL}^{-1}$ pour chaque agent pathogène, avec les durées d'humectation de $24-48 \mathrm{~h}$ et une température d'incubation supérieure à $12^{\circ} \mathrm{C}$. 


\title{
Evaluation of interactions between Rhynchosporium secalis and Pyrenophora teres on barley
}

\author{
Allen G. Xue ${ }^{1}$ and Peter A. Burnett ${ }^{2}$ \\ Received 1994-04-07; accepted 1995-03-22
}

\begin{abstract}
Interactions between Rhynchosporium secalis and Pyrenophora teres were investigated on barley (Hordeum vulgare) seedlings grown in a greenhouse and growth chambers. Following mixed inoculations, the two pathogens colonized the same leaf simultaneously, but the leaf area with symptoms (LAS) was less than that produced by either of the two pathogens alone at the same inoculum concentration. On plants inoculated with the mixed inocula, LAS induced by $R$. secalis was reduced by a greater amount than LAS induced by $P$. teres. The predominance of $P$. teres over $R$. secalis was observed even when inoculations with $R$. secalis either preceded or followed the inoculation with $P$. teres by $24 \mathrm{~h}$. Antagonism occurred when inoculum densities were $10^{3}-10^{4}$ spores $\mathrm{mL}^{-1}$ for each pathogen, wetting periods were $24-28 \mathrm{~h}$, and incubation temperature was above $12^{\circ} \mathrm{C}$.
\end{abstract}

Xue, A.G. et P.A. Burnett. 1995. Évaluation des interactions entre le Rhynchosporium secalis et le Pyrenophora teres chez l'orge. PHYTOPROTECTION 76: 1-7.

Les interactions entre le Rhynchosporium secalis et le Pyrenophora teres ont été étudiées sur des plantules d'orge (Hordeum vulgare) cultivées dans une serre et dans des chambres de croissance. À la suite d'inoculations mixtes, les deux agents pathogènes ont colonisé la même feuille simultanément, mais la surface foliaire portant des symptômes était moindre que celle produite par l'un ou l'autre des deux agents pathogènes utilisés seuls à la même concentration d'inoculum. Sur les plantes inoculées avec les inoculums mixtes, la surface foliaire portant des symptômes induits par le $R$. secalis était grandement inférieure à celle induite par le $P$. teres. La prédominance du $P$. teres sur le $R$. secalis a même été observée quand les inoculations avec le $R$. secalis précédait ou suivait l'inoculation avec le $P$. teres par $24 \mathrm{~h}$. Un antagonisme s'est produit quand les concentrations d'inoculum étaient de $10^{3}-10^{4}$ spores $\mathrm{mL}^{-1}$ pour chaque agent pathogène, avec les durées d'humectation de $24-48$ h et une température d'incubation supérieure à $12^{\circ} \mathrm{C}$.

\section{INTRODUCTION}

Rhynchosporium secalis (Oudem.) J.J. Davis, the causal agent of scald, and Pyrenophora teres (Died.) Drechsl., the causal agent of net blotch, are the two most common pathogens of barley (Hordeum vulgare L.) in the world (Mathre 1982; Shipton etal. 1974). Both organisms are commonly present on barley leaves and the diseases they induce are frequently observed on the same plant in a field (Xue

1. Agriculture and Agri-Food Canada, Agri-Food Diversification Research Centre, Unit 100-101 Route 100, Morden, Manitoba, Canada R6M 1Y5

2. Agriculture and Agri-Food Canada, Lacombe Research Centre, Bag Service 5000, Lacombe, Alberta, Canada TOC 1S0. Contribution No. 769. Agriculture and Agri-Food Canada Research Centre, Lacombe, Alberta 
etal. 1994). Numerous studies have shown that both $R$. secalis and $P$. teres may cause large reductions in yield and grain quality of barley (Shipton et al. 1974). However, no information is available on the occurrence and importance of interactions between the two pathogens. Cook and Baker (1983) stated that when two or more plant pathogens attack the same plant organ, the organisms may interact antagonistically, synergistically, or exhibit neutralism toward each other. These interactions, therefore, may significantly influence the development of diseases on host plants. This study was conducted to examine the interactions between $R$. secalis and $P$. teres on barley leaves, and to determine the impact of biotic and abiotic factors on the occurrence of the interactions.

\section{MATERIALS AND METHODS}

\section{Fungal isolates and inoculum production}

Single conidial isolates coded LRS9205 (R. secalis) and LPT9207 (P. teres) were used in all the experiments. These isolates were obtained from naturally infected barley cv. Harrington, grown at the Agriculture and Agri-Food Canada, Lacombe Research Centre, Lacombe (52 ${ }^{\circ} 5^{\prime} \mathrm{N}$ 11330' W), Alberta, in 1992. Cultures of LRS9205 were maintained at $4^{\circ} \mathrm{C}$ on wheat germ agar (WGA) (Xue et al. 1991) and LPT9207 on V-8 juice agar (V8).
Inoculum of $R$. secalis was produced in petri dishes on WGA supplemented with $100 \mu \mathrm{L} \mathrm{L}^{-1}$ of streptomycin (Xue and Hall 1991). Conidia from 21-d-old cultures were harvested by flooding the cultures with distilled water containing $0.01 \%$ Tween 20 (polyoxyethylene sorbitan) and rubbing gently with a sterile, latex-tipped glass rod to dislodge spores. The resulting spore suspension was filtered through two layers of cheesecloth and adjusted to the desired concentration with the aid of a haemocytometer.

Inoculum of $P$. teres was produced by growing the fungus on $V 8$ in petri dishes with $100 \mu \mathrm{L} \mathrm{L}^{-1}$ of streptomycin. The petri dishes were incubated for $10 \mathrm{~d}$ at $17 \pm 1^{\circ} \mathrm{C}$, with a $14-\mathrm{h}$ photoperiod under cool white fluorescent lamps. Conidial suspensions for inoculations were prepared using the same method described for $R$. secalis.

\section{Growth of barley in greenhouse and growth chambers}

Pedigree seeds of the barley cultivars Harrington, Klages, Diamond, Leduc, Empress and Johnston were used in the interaction studies. The susceptibility of these cultivars to $R$. secalis and $P$. teres is shown in Table 1.

Groups of five barley plants were grown in 14-cm-diam plastic pots containing a soil:perlite:peat moss mixture (1:1:1,v:v:v) in a greenhouse maintained at $23 \pm 1^{\circ} \mathrm{C}$ during the day and $20 \pm 1{ }^{\circ} \mathrm{C}$ during the

Table 1. Reaction of six barley cultivars to Rhynchosporium secalis (Rs) and Pyrenophora teres (Pt) alone and in combination

\begin{tabular}{|c|c|c|c|c|c|c|c|c|c|c|c|c|}
\hline \multirow[b]{4}{*}{ Cultivar } & \multirow{3}{*}{\multicolumn{2}{|c|}{$\begin{array}{l}\text { Reaction to } \\
\text { pathogen }\end{array}$}} & \multicolumn{5}{|c|}{$\operatorname{LAS}^{\xi}(\%)$} & \multirow{3}{*}{\multicolumn{5}{|c|}{$\begin{array}{c}\text { Contrast among means } \\
\text { ( } t \text { value })\end{array}$}} \\
\hline & & & \multicolumn{3}{|c|}{ Mixed inoculum } & \multirow{3}{*}{$\begin{array}{l}\text { Rs } \\
\text { (4) }\end{array}$} & \multirow{3}{*}{$\begin{array}{l}\mathrm{Pt} \\
(5)\end{array}$} & & & & & \\
\hline & & & Rs & $\mathrm{Pt}$ & Total & & & & & & & \\
\hline & Rs & $\mathrm{Pt}$ & (1) & (2) & (3) & & & (1) vs (2) & (1) vs (4) & (2) vs (5) & (3) vs (4) & (3) vs (5) \\
\hline Harrington & S & S & $6 \mathrm{~b}$ & 39 a & $45 a$ & $56 a$ & $67 a$ & $8.63^{* *}$ & $6.83^{* *}$ & $4.23^{* *}$ & 1.10 & $3.32^{*}$ \\
\hline Klages & $S$ & $S$ & $13 a$ & $34 a b$ & 47 a & 61 a & $67 a$ & $4.27^{* *}$ & $7.74^{* *}$ & $4.41^{* *}$ & 1.45 & $2.32^{*}$ \\
\hline Diamond & MR & $M R$ & $2 b c$ & $23 b c$ & $25 b$ & $47 a b$ & $46 \mathrm{~b}$ & $4.40^{* *}$ & $11.23^{* *}$ & $4.02^{* *}$ & $4.40^{* *}$ & $4.60^{* *}$ \\
\hline Leduc & MR & MR & $1 \mathrm{c}$ & $11 \mathrm{c}$ & $12 b$ & $44 a b$ & $42 \mathrm{C}$ & $3.69 * *$ & $13.57^{* *}$ & $4.97^{* *}$ & $9.70 * *$ & $4.86^{* *}$ \\
\hline Empress & $\mathrm{R}$ & $S$ & $4 \mathrm{bc}$ & $38 a b$ & $42 a$ & $19 \mathrm{~b}$ & $67 \mathrm{~b}$ & $14.60 * *$ & 1.40 & $4.56^{* *}$ & 2.14 & $4.98 * *$ \\
\hline Johnston & $R$ & $S$ & $3 b c$ & 45 a & $48 \mathrm{a}$ & $2 c$ & $64 a b$ & $19.19 * *$ & 0.22 & $5.01^{* *}$ & $11.90 * *$ & $3.71^{* *}$ \\
\hline
\end{tabular}

S: susceptible; R: resistant; MR: moderately resistant.

LAS: Leaf area with symptoms.

Means followed by the same letter within a column are not significantly different at $P \leq 0.05$ (LSD).

* = significant at $P \leq 0.05 ;{ }^{*}=$ significant at $P \leq 0.01$. 
night. Plants were watered twice weekly from the base. The potting mixture contained sufficient nutrients to support healthy plant growth for the course of the experiments. Supplemental light was provided by $400 \mathrm{~W}$ metal halide lamps to ensure a 14-h photoperiod and a light intensity of $150 \mu \mathrm{mol} \mathrm{m}^{-2} \mathrm{~s}^{-1}$.

\section{Inoculation}

Plants were inoculated at Zadoks growth stage 15 (Zadoks et al. 1974), which occurred 16-18 d after seeding. Spore suspensions of $R$. secalis and $P$. teres were prepared and adjusted to $5 \times 10^{3}$ conidia $\mathrm{mL}^{-1}$. Mixed inocula of $R$. secalis and $P$. teres were prepared by taking half volume of each pathogen from previously prepared spore suspensions of $10^{4}$ conidia $\mathrm{mL}^{-1}$ per pathogen $\left(5 \times 10^{3}\right.$ conidia $\mathrm{mL}^{-1}$ of each pathogen). The inocula were sprayed on whole plants at a rate of $0.5 \mathrm{~mL}$ plant ${ }^{-1}$ using a DeVilbiss model 15 atomizer (The DeVilbiss Co., Somerset, Pennsylvania). After allowing the inocula to dry for $30 \mathrm{~min}$, the plants were transferred to a humidity chamber at $20 \pm 1^{\circ} \mathrm{C}$ for a period of $48 \mathrm{~h}$, then returned to the greenhouse bench or growth chambers. The saturated atmosphere in the humidity chamber was maintained by a mist produced by an ultrasonic humidifier and monitored with a hygrothermograph. Treatments were arranged in a randomized complete block design with four replicate pots. Four pots of cv. Harrington sprayed with distilled water plus $0.01 \%$ Tween 20 were included with each experiment as checks against extraneous airborne inocula. All experiments were repeated two times.

\section{Factors affecting interactions between $R$. secalis and $P$. teres}

The relationship between inoculation sequence, inoculum concentration, wetting period and incubation temperature, and interactions between $R$. secalis and $P$. teres was examined in five experiments using barley cv. Harrington. In all the experiments, plants were inoculated with the combination of the two pathogens (1:1, vol:vol). Plants inoculated with each pathogen individually were included as checks. Conidial suspensions used for inoculations were adjusted to $5 \times 10^{3}$ spores $\mathrm{mL}^{-1}$ or $5 \times 10^{3}$ conidia $\mathrm{mL}^{-1}$ of each pathogen in mixed inocula, except in experiments to observe the effect of inoculum concentration.

\section{Inoculation sequence and inoculum concentration}

To determine the effect of inoculation sequence, five different sequences of treatment with $R$. secalis $(\mathrm{Rs}), P$. teres $(\mathrm{Pt})$, or the mixed inocula of the two pathogens were carried out. The respective combinations were coded Rs-Rs, Rs-Pt, $\mathrm{Pt}-\mathrm{Pt}$, Pt-Rs, and (Rs+Pt)-(Rs+Pt) (Table 2). Following the first inoculation, plants were placed in the humidity chamber for 24-h and then moved out. Surface moisture was evaporated from the plants within $15 \mathrm{~min}$ with a fan at room temperature. The second inoculation was done immediately after surface moisture evaporation. These plants were returned to the humidity chamber for another 24-h wetting period. Upon completion of the second wetting period, plants were dried for 15 min with the fan and transferred to the greenhouse bench.

Table 2. Effect of inoculation sequence on the interactions between Rhynchosporium secalis (Rs) and Pyrenophora teres (Pt) on barley

\begin{tabular}{cccc}
\hline & \multicolumn{3}{c}{ LAS $^{\xi}(\%)$} \\
\cline { 2 - 4 } Inoculation sequence & $\mathrm{Rs}$ & $\mathrm{Pt}$ & Total \\
\hline $\mathrm{Rs}-\mathrm{Rs}$ & $64.2 \mathrm{a}^{\dagger}$ & - & $64.2 \mathrm{~b}$ \\
$\mathrm{Rs}-\mathrm{Pt}$ & $9.9 \mathrm{~b}$ & $42.9 \mathrm{~b}$ & $52.8 \mathrm{c}$ \\
$\mathrm{Pt}-\mathrm{Pt}$ & - & $74.0 \mathrm{a}$ & $74.0 \mathrm{a}$ \\
$\mathrm{Pt}-\mathrm{Rs}$ & $1.2 \mathrm{c}$ & $52.0 \mathrm{~b}$ & $53.6 \mathrm{c}$ \\
(Rs+Pt) - (Rs+Pt) & $3.6 \mathrm{c}$ & $32.5 \mathrm{c}$ & $36.1 \mathrm{~d}$ \\
\hline
\end{tabular}

$\xi$ LAS: Leaf area with symptoms.

$\uparrow$ Means within a column followed by the same letter are not significantly different at $P \leq 0.05$ (LSD). 
The effect of different concentrations of inocula on interactions between the pathogens was tested using five concentrations of inocula $\left(10^{2}, 10^{3}, 5 \times 10^{3}\right.$, $10^{4}$ and $10^{5}$ spores $\mathrm{mL}^{-1}$ pathogen ${ }^{-1}$ ). Inoculated plants were kept $48 \mathrm{~h}$ in a humidity chamber and returned to the greenhouse bench as described above.

\section{Wetting period and temperature}

The effects of wetting period and temperature were studied in three experiments. In the first experiment, inoculated plants were placed in the humidity chamber for $0.5-48 \mathrm{~h}$ and returned to the greenhouse bench for disease development. In the second experiment, inoculated plants were exposed to a wetting period of $48 \mathrm{~h}$ and then transferred to growth chambers adjusted to $5,10,17$ and $25 \pm 1{ }^{\circ} \mathrm{C}$. Each chamber was operated with a 14-h photoperiod and a photosynthetic photon flux density of $150 \mu \mathrm{mol} \mathrm{m} \mathrm{m}^{-2} \mathrm{~s}^{-1}$ provided by fluorescent and incandescent lamps. In the third experiment, the combination of four wetting periods $(12,24,36$ or $48 \mathrm{~h})$ and three temperatures $\left(10,17\right.$ and $\left.25^{\circ} \mathrm{C}\right)$ was studied. After each wetting period, inoculated plants were dried for $15 \mathrm{~min}$ with a fan and placed in each of the three temperature-controlled chambers.

\section{Disease assessment and statistical analysis}

The severity of scald and net blotch was estimated for each inoculated leaf using a scale in which the percentage values are leaf area with symptoms $10=0 \%, 1=$ $1-5 \%, 2=6-10 \%, 3=11-20 \%, 4=21-30 \%$, $5=31-50 \%, 6=51-75 \%$, and $7=$ $76-100 \%)$. The scale was modified from that of Horsfall and Cowling (1978). Disease severity scores were converted to percentage of leaf area with symptoms (LAS) from Eq. [1].

Inoculated plants were rated for disease severity on the $2^{\text {nd }}, 3^{\text {rd }}$, and $4^{\text {th }}$ leaves $14 \mathrm{~d}$ after inoculation. Analysis of variance was conducted using Statistical Analysis System (SAS) (Cody and Smith 1991) and treatment means were separated by the least significant difference (LSD) test or by a Student's $t$ test at a probability level of 0.05 .

\section{RESULTS AND DISCUSSION}

\section{Interactions between $R$. secalis and $P$. teres}

Both $R$. secalis and $P$. teres developed simultaneously on the same leaf after inoculation with the mixed inocula. The appearance of scald and net blotch when they developed simultaneously on the same leaf was slightly changed from their appearance when they developed separately. Scald lesions were often changed from the normal eye-shape to an irregular shape, and did not show the typical dark brown margin when in contact with necrotic areas caused by $P$. tere's. Net blotch development was also retarded in the presence of scald and lesions tended to be shorter in length. On all the cultivars inoculated with the mixed inocula, more net blotch developed than did scald. The proportions of leaf area colonized by scald and net blotch were on average $4.8 \%$ and $31.5 \%$, respectively. Contrast between the two diseased proportions was significant at $P<0.001$. In most instances, the total LAS were reduced when both pathogens were present on the leaves compared with the effect of each pathogen individually (Table 1). From this standpoint, we suggest that the interactions between the two pathogens were antagonistic. Depending on resistance to the individual pathogens, the cultivars used in this study had a different impact on the occurrence and the intensity of the interactions. When both pathogens were applied simultaneously, cv. Diamond and Leduc, which are moderately resistant to both pathogens, showed significant reduction $(P<0.01)$ in total LAS compared to inoculations with each pathogen individually. Oncv. Klages and Harrington, which are susceptible to both pathogens, and cv. Empress and Johnston, which were resistant to $R$. secalis but susceptible to $P$. teres (Table 1 ), the reductions in total LAS were significant $(P<0.05)$ only' when

$$
\text { LAS }=\frac{\sum\left(\begin{array}{c}
\text { median value } \\
\text { in a category }
\end{array} \times \begin{array}{c}
\text { number of leaves } \\
\text { in the category }
\end{array}\right)}{\text { total number of leaves }}
$$


compared to that from the inoculation with $P$. teres alone (Table 1).

The LAS on plants inoculated twice consecutively with $R$. secalis or with $P$. teres were significantly greater than those on plants with sequential inoculation of one pathogen followed by another (Table 2). The lowest LAS was obtained on plants inoculated twice consecutively with the mixed inocula. Diseases induced on plants inoculated twice consecutively with mixed inocula or with sequential inoculations of one pathogen followed by another had less scald than net blotch. The fewest symptoms of scald were observed on plants when $R$. secalis was applied $24 \mathrm{~h}$ after the inoculation with $P$. teres. We observed that the scald pathogen colonized only unaffected tissues. If $P$. teres was already present on a leaf, $R$. secalis usually did not develop, or if it did, it was only on the lower portion of the leaf, which was not usually affected by net blotch.

\section{Effects of inoculum concentration, wetting period and incubation temperature}

Neither scald nor net blotch developed on plants inoculated with spore suspensions lower than $10^{2}$ conidia $\mathrm{mL}^{-1}$. Both diseases were observed and the total LAS increased markedly with the increase of inoculum concentration from $10^{2}$ to $10^{5}$ conidia $\mathrm{mL}^{-1}$ for each pathogen. The total LAS induced by the mixed inocula were significantly lower than those induced by each pathogen alone at the inoculum concentrations of $10^{3}$ to $5 \times 10^{3}$, but not at $10^{2}$ or above $10^{4}$ conidia $\mathrm{mL}^{-1}$ pathogen ${ }^{-1}$. As the inoculum concentration increased to $10^{5}$ conidia $\mathrm{mL}^{-1}$, plants receiving either mixed inocula or each pathogen alone withered and leaf necroses caused by the individual pathogens could not be differentiated (Table 3).

Table 3. Effects of inoculum concentration, wetting period and incubation temperature on the interactions between Rhynchosporium secalis (Rs) and Pyrenophora teres (Pt) on barley

\begin{tabular}{|c|c|c|c|c|c|c|c|c|c|c|}
\hline \multirow[b]{4}{*}{ Factor } & \multicolumn{5}{|c|}{ LAS $^{\psi}(\%)$} & \multirow{3}{*}{\multicolumn{5}{|c|}{$\begin{array}{c}\text { Contrast among means } \\
(t \text { value })\end{array}$}} \\
\hline & \multicolumn{3}{|c|}{ Mixed inoculum } & \multirow{3}{*}{$\begin{array}{l}\text { Rs } \\
\text { (4) }\end{array}$} & \multirow{3}{*}{$\begin{array}{l}\text { Pt } \\
(5)\end{array}$} & & & & & \\
\hline & $\overline{\text { Rs }}$ & $\mathrm{Pt}$ & Total & & & & & & & \\
\hline & (1) & (2) & (3) & & & (1) vs (2) & (1) vs (4) & (2) vs (5) & (3) vs (4) & (3) vs (5) \\
\hline \multicolumn{11}{|c|}{ Inoculum concentration (spores $\mathrm{mL}^{-1}$ pathogen ${ }^{-1}$ ) } \\
\hline $1 \times 10^{2}$ & 1 & 2 & 3 & 3 & 2 & $1.22^{*}$ & $2.65^{*}$ & 0.61 & 0.05 & 0.85 \\
\hline $1 \times 10^{3}$ & 4 & 10 & 14 & 39 & 17 & $2.46^{*}$ & $14.41 * *$ & $2.79^{*}$ & $8.02^{* *}$ & $1.01^{*}$ \\
\hline $5 \times 10^{3}$ & 10 & 30 & 40 & 52 & 57 & $6.88^{* *}$ & $20.46^{* *}$ & $5.40^{* *}$ & $6.38 * *$ & $3.47^{*}$ \\
\hline $1 \times 10^{4}$ & 15 & 37 & 52 & 52 & 58 & $7.30 * *$ & $9.40 * *$ & $7.02^{* *}$ & 0.23 & $2.52^{*}$ \\
\hline $1 \times 10^{5}$ & $x^{\dagger}$ & $x$ & 88 & 88 & 88 & $-^{\ddagger}$ & - & - & 0.01 & 0 \\
\hline \multicolumn{11}{|c|}{ Wetting period $(h)^{\varepsilon}$} \\
\hline 0.5 & 0 & 0 & 0 & 0 & 0 & - & - & - & - & - \\
\hline 4 & 0 & 0 & 0 & 1 & 0 & - & 1.00 & - & 1.00 & - \\
\hline 8 & 0 & 5 & 5 & 1 & 5 & $4.01 *$ & $4.50^{*}$ & 0.15 & 3.67 & 0.15 \\
\hline 12 & 1 & 3 & 4 & 3 & 28 & 2.90 & 2.90 & $7.45^{*}$ & 0.49 & $7.45^{*}$ \\
\hline 24 & 4 & 17 & 21 & 42 & 57 & 3.94 & $8.74^{*}$ & $10.30^{* *}$ & $4.95^{*}$ & $9.22^{*}$ \\
\hline 36 & 9 & 18 & 27 & 58 & 52 & 3.10 & $8.55^{*}$ & $6.70^{*}$ & $5.20^{*}$ & $8.25^{*}$ \\
\hline 48 & 7 & 28 & 35 & 59 & 63 & $4.89 *$ & $22.70 * *$ & $8.45^{*}$ & $10.78^{* *}$ & $13.71^{* * *}$ \\
\hline \multicolumn{11}{|c|}{ Incubation temperature $\left({ }^{\circ} \mathrm{C}\right)^{\xi}$} \\
\hline 5 & 5 & 2 & 7 & 5 & 13 & 2.24 & 0.18 & $4.57^{* *}$ & 2.06 & $2.87^{*}$ \\
\hline 10 & 10 & 12 & 22 & 35 & 37 & 1.40 & $5.41^{*}$ & $5.49 * *$ & $2.97^{*}$ & $5.62 * *$ \\
\hline 17 & 14 & 17 & 31 & 56 & 46 & 2.03 & $13.60 * *$ & $9.00 * *$ & $10.60^{* *}$ & $5.86^{* *}$ \\
\hline 25 & 3 & 20 & 23 & 37 & 55 & $6.47^{* *}$ & $11.80^{* *}$ & $11.53^{* *}$ & $4.21 *$ & $11.19 * *$ \\
\hline \multicolumn{11}{|c|}{$\begin{array}{l}\text { "LAS: Leaf area with symptoms. } \\
\text { Conidial suspensions used for inoculations were adjusted to } 5 \times 10^{3} \text { spores } \mathrm{mL}^{-1} \text { or } 5 \times 10^{3} \mathrm{con} \\
\mathrm{mL}^{-1} \text { of each pathogen in mixed inocula. } \\
{ }^{+} \text {Plants withered, leaf necroses caused by individual pathogens can not be differentiated. } \\
{ }^{*}=\text { significant at } P \leq 0.05 ;{ }^{*}=\text { significant at } P \leq 0.01 \text {. } \\
{ }^{*} \text { Student's } t \text { test cannot be applied. }\end{array}$} \\
\hline
\end{tabular}


At the incubation temperature of $23 \pm 1{ }^{\circ} \mathrm{C}$, no scald developed on plants inoculated with $R$. secalis alone when the wetting period was $<1 \mathrm{~h}$ nor on plants inoculated with the mixed inocula when the wetting period was $\leq 8 \mathrm{~h}$. Net blotch was not observed on plants inoculated with either $P$. teres alone or the combination of $P$. teres and $R$. secalis when the wetting period was $<4 \mathrm{~h}$. Both scald and net blotch were observed and LAS increased with the increase of wetting period from 4 to $48 \mathrm{~h}$. When the wetting period was in the range of 12-48 $h$, the total LAS of plants inoculated with mixed inocula were significantly lower $(P<0.05)$ than that of plants inoculated with an individual pathogen. The reduction in total LAS was greatest when the wetting period was $48 \mathrm{~h}$ (Table 3 ).

Regardless of whether the inoculation of plants was with each pathogen alone or with a combination of the two organisms, severity of scald increased with the increase of temperature from 5 to $17^{\circ} \mathrm{C}$, and severity of net blotch increased with the increase of temperature from 5 to $25^{\circ} \mathrm{C}$, when the wetting period was $48 \mathrm{~h}$. When the temperature increased from 10 to $25^{\circ} \mathrm{C}$, the total LAS of plants inoculated with the mixed inocula were significantly lower $(P<0.05)$ compared to that of plants inoculated with each pathogen separately. On plants inoculated with the mixed inocula, the greatest reduction for scald was at $17^{\circ} \mathrm{C}$, and for net blotch at $25^{\circ} \mathrm{C}$ (Table 3).

The combined effects of wetting period and incubation temperature on severity of the diseases and on interactions of the two pathogens are shown in Figure 1. At all the temperatures tested, scald and net blotch increased with the increase of wetting period from 12 to $48 \mathrm{~h}$. On plants inoculated with either $R$. secalis or $F$. teres alone, the maximum severity of scald and net blotch was achieved with a $48 \mathrm{~h}$ wetting period, at temperatures of 17 and $25^{\circ} \mathrm{C}$, respectively. Under each of the treatment combinations of wetting period and temperature, plants inoculated with the mixed inocula of the two pathogens developed less scald compared with net blotch. The total LAS on these plants were similar or smaller than those affected by each pathogen separately.

Although interactions among pathogenic microorganisms have been reported

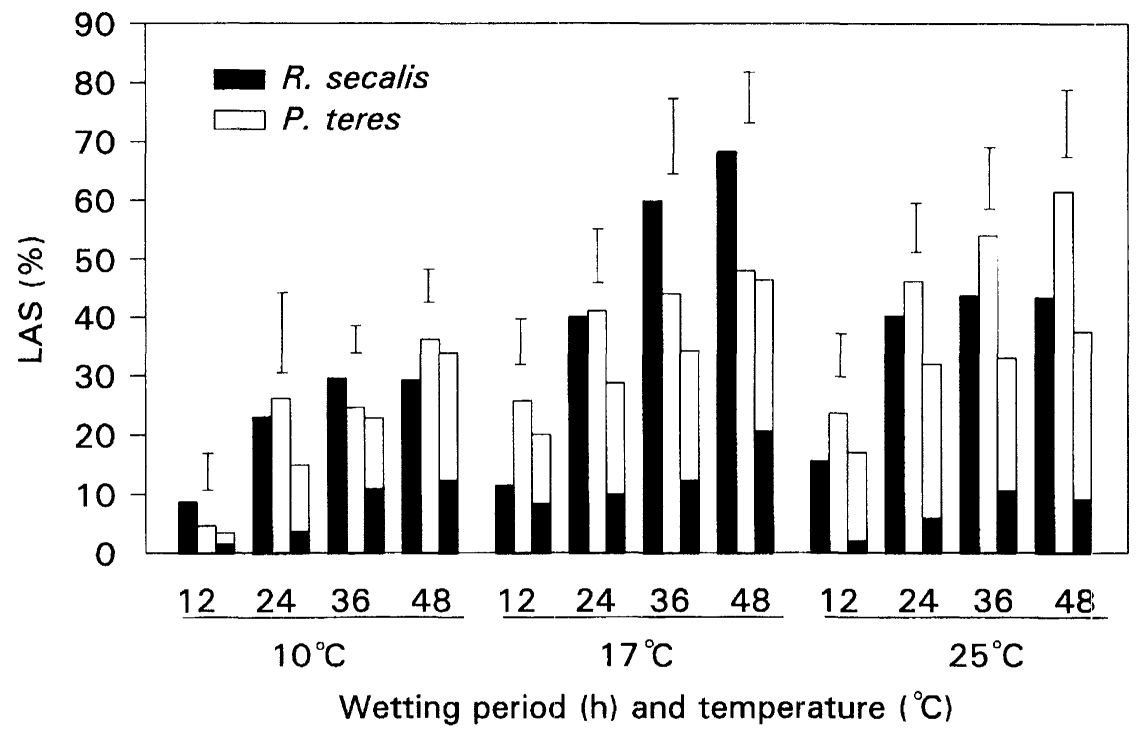

Figure 1. Combined effects of wetting period and incubation temperature on the interactions between Rhynchosporium secalis and Pyrenophora teres on leaves of barley cv. Harrington. Simple and stacked columns represent single and combined inoculations, respectively. Vertical bars indicate LSD values at $P \leq 0.05$. LAS: Leaf area with symptoms. 
on barley and other cereal crops (da Luz and Bergstom 1987; Madariaga and Scharen 1986; Pauvert et al. 1978; Simkin and Wheeler 1974; Spadafora and Cole 1987), no study has been done on factors affecting their interactions. It seems possible that certain biotic and abiotic factors may affect the expression of any possible interactions among the pathogenic organisms. Further studies are needed to verify the occurrence of the antagonistic interactions in a field situation where both pathogens are present and to determine the possible effect of such interactions on disease development and yield reductions.

\section{ACKNOWLEDGEMENTS}

We wish to thank Mr. Ralph Lange for his technical assistance, Drs. Neil K. Harker and John S. Taylor for reading the manuscript and making valuable suggestions, and Jim Helm of the Field Crop Development Centre, Alberta Agriculture, Lacombe, Alberta, for supplying seeds. Financial support from the Natural Science and Engineering Research Council of Canada through Visiting Fellowships in Canadian Government Laboratories, and Alberta Agriculture through a Farming for the Future grant, is gratefully acknowledged.

\section{REFERENCES}

Cody, R.P., and J.K. Smith. 1991. Applied statistics and SAS - Programming language. $3^{\text {rd }}$ edition. SAS Institute Inc., Cary, North Carolina. 403 pp.

Cook, R.J., and K.F. Baker. 1983. Components of biological control. Pages 57-83 in The nature and practice of biological control of plant pathogens. The American Phytopathological Society. St. Paul, Minnesota.

da Luz, W.C., and G.C. Bergstrom. 1987. Interactions between Cochliobolus sativus and Pyrenophora tritici-repentis on wheat leaves. Phytopathology 77 : 1355-1360.
Horsfall, J.G., and E.B. Cowling. 1978. Pathometry : the measurement of plant disease. Pages 120-136 in J.G. Horsfall and E.B. Cowling (eds.), Plant disease : an advanced treatise, Vol. 2. Academic Press, New York.

Madariaga, B.R., and A.L. Scharen. 1986. Interactions of Puccinia striiformis and Mycosphaerella graminicola on wheat. Plant Dis. 70 : 651-654.

Mathre, D.E. 1982. Compendium of barley diseases. The American Phytopathological Society. St. Paul, Minnesota. 78 pp.

Pauvert, P., M. Thomas, B. Tullaye, and B. de La. 1978. An attempt at a quantitative interpretation of powdery mildew and Rhynchosporium epidemics. Ann. Phytopathol. 10 : 405-415.

Shipton, W.A., W.J.R. Boyd, and S.M. Ali. 1974. Scald of barley. Rev. Plant Pathol. 53 : 839861.

Simkin, M.B., and B.E.J. Wheeler. 1974. Effects of dual infections of Puccinia hordei and Erysiphe graminis on barley, cv. Zephyr. Ann. Appl. Biol. 78 : 237-250.

Spadafora, V.J., and H. Cole Jr. 1987. Interactions between Septoria nodorumleaf blotch and leaf rust on soft red winter wheat. Phytopathology 77 : 1308-1310.

Xue, G., and R. Hall. 1991. Components of parasitic fitness in Rhynchosporium secalis and quantitative resistance to scald in barley as determined with a dome inoculation chamber. Can. J. Plant Pathol. 13: 19-25.

Xue, G., R. Hall, and D. Falk. 1991. Pathogenic variation in Rhynchosporium secalis from southern Ontario. Plant Dis. 75 : 934-938.

Xue, G., P.A. Burnett, and J. Helm. 1994. Severity of, and resistance of barley varieties to, scald and net blotch in central Alberta. Can. Plant Dis. Surv. $74:$ 13-17.

Zadoks, J.C., T.T. Chang, and C.F. Konzak. 1974. A decimal code for growth stages of cereals. Weed Res. $14: 415-421$. 